\title{
Quantifying regional, time-varying effects of cropland and pasture on vegetation fire
}

\author{
S. S. Rabin ${ }^{1}$, B. I. Magi ${ }^{2}$, E. Shevliakova ${ }^{3}$, and S. W. Pacala ${ }^{1}$ \\ ${ }^{1}$ Princeton University, Dept. of Ecology and Evolutionary Biology, Princeton, NJ, USA \\ ${ }^{2}$ University of North Carolina at Charlotte, Geography and Earth Sciences Department, Charlotte, NC, USA \\ ${ }^{3}$ GFDL-Princeton University Cooperative Institute for Climate Science, Princeton, NJ, USA \\ Correspondence to: S. S. Rabin (srabin@princeton.edu)
}

Received: 24 June 2015 - Published in Biogeosciences Discuss.: 10 July 2015

Revised: 23 October 2015 - Accepted: 5 November 2015 - Published: 19 November 2015

\begin{abstract}
The global extent of agriculture demands a thorough understanding of the ways it impacts the Earth system through the modification of both the physical and biological characteristics of the landscape as well as through emissions of greenhouse gases and aerosols. People use fire to manage cropland and pasture in many parts of the world, impacting both the timing and amount of fire. So far, much previous research into how these land uses affect fire regimes has focused on either individual small regions or global patterns at annual or decadal scales. Moreover, because pasture is not mapped globally at high resolution, the amount of fire associated with pasture has never been quantified as it has for cropland. The work presented here resolves the effects of agriculture - including pasture - on fire on a monthly basis for regions across the world, using globally gridded data on fire activity and land use at $0.25^{\circ}$ resolution. The first global estimate of pasture-associated fire reveals that it accounts for over $40 \%$ of annual burned area. Cropland, generally assumed to reduce fire occurrence, is shown to enhance or suppress fire at different times of year within individual regions. These results bridge important gaps in the understanding of how agriculture and associated management practices influence vegetation fire, enabling the next generation of vegetation and Earth system models more realistically incorporate these anthropogenic effects.
\end{abstract}

\section{Introduction}

Vegetation fire is a worldwide phenomenon with consequences for the biosphere, atmosphere, climate, and human health. Annual emissions of carbon (in various chemical forms) from fire have been estimated at $2.5 \mathrm{Pg} \mathrm{yr}^{-1}$ (20012009; Randerson et al., 2012). The radiative forcing from the black carbon emitted from fires since 1750 has been estimated to be $0.2 \mathrm{~W} \mathrm{~m}^{-2}$, which is about equivalent to $12 \%$ of radiative forcing due to the accumulated anthropogenic $\mathrm{CO}_{2}$ over the same time period (Bond et al., 2013; Myhre et al., 2013). Other gas and aerosol emissions from biomass burning can have notable impacts on atmospheric composition and regional weather (Crutzen and Andreae, 1990; Cox et al., 2008). Many ecosystems are shaped by fire (or the lack thereof): the frequency and seasonal timing of burns are integral to what is known as a fire regime, changes to which can, over time, result in shifts to different ecosystem types (Pyne et al., 1996b; Archibald et al., 2013; Scott et al., 2014). Model simulations of an Earth without fire have resulted in about twice as much forest area (Bond et al., 2005) or nearly $30 \%$ more carbon stored in land ecosystems (Ward et al., 2012), which illustrates the important role that fire plays in the global carbon cycle.

Humans have been manipulating fire regimes for at least several thousand years, with anthropogenic influence having grown considerably since the Industrial Revolution (Marlon et al., 2008; Bowman et al., 2011; Archibald et al., 2012). People have suppressed wildfire actively to protect lives and property, and passively by creating landscapes that inhibit large-scale fire spread. Humans have also induced burning 
both intentionally and unintentionally (Pyne et al., 1996a; Bowman et al., 2011). Such anthropogenic influences can result in fire regimes that differ in important ways from how ecosystems would burn in the absence of humans, such as in terms of frequency, severity, and seasonality. For example, evidence suggests that burning often does not occur during the period of the year with peak flammability, likely reflecting human fire practices at local to regional scales rather than natural or even accidental ignitions (Le Page et al., 2010; Magi et al., 2012). In order to understand the changes humanity has made to fire regimes and how patterns of vegetation fire will continue into the future, we must identify and interpret the signatures of different human activities on observed fire patterns.

One widespread example of humans' influence on fire regimes is prescribed burning for agricultural management. Farmers may use fire to prepare fields for planting or to dispose of waste after harvest (Yevich and Logan, 2003); pastoralists can burn to enhance forage nutrient content or prevent woody encroachment (Uhl and Buschbacher, 1985). The presence of cropland or heavily grazed pasture can also reduce fire in the surrounding landscape by limiting fire spread (Archibald et al., 2009; Andela and van der Werf, 2014). Land managers sometimes take advantage of a similar effect by burning small patches of land surrounding their property, reducing the chances that a burn could spread into their fields (Laris, 2002). Fire amplification can happen as well, with agricultural management fires spreading onto nonagricultural lands. The total worldwide influence of these and other effects of agriculture on vegetation fire is poorly understood, even though cropland and pasture respectively accounted for 11 and $24 \%$ of the Earth's land area at the beginning of this century (Klein Goldewijk et al., 2010).

Dynamic global vegetation models and Earth system models often include process-based simulations of vegetation fires (e.g., Lenihan et al., 1998; Arora and Boer, 2005; Thonicke et al., 2010). Human influence is usually included as a function of population density (Venevsky et al., 2002; Pechony and Shindell, 2009), although some authors have noted that such relationships are too simplistic, with the effect of population density actually varying based on biome or amount and type of land use (Bistinas et al., 2013). Recent work has included the suppressive effect associated with cropland through landscape fragmentation (Pfeiffer et al., 2013; Le Page et al., 2015). These effects of humans in global models are based on analyses done at the scale of individual regions (e.g., Archibald et al., 2009) or the entire globe (e.g., Bistinas et al., 2014). Bistinas et al. (2014), for example, found that fire is negatively correlated with cropland but positively correlated with pasture, taking into account a number of other variables. Such findings, however, do not fully capture the complexity and multitude of effects that managed ecosystems can have on fire. It is possible, for instance, that farmers in some part of the world might burn cropland during an otherwise fire-free season, but that in drier parts of the year cropland could fragment the burnable landscape and thus have a suppressive effect on fire. Remote sensing data from satellites can partially fill in such gaps: estimates of burning on different land cover types are generated by overlaying fire activity data with maps of land-use and vegetation type, including cropland, which are produced by some of the same satellites (Korontzi et al., 2006; Giglio et al., 2010). For example, such estimates were used by Li et al. (2013) to incorporate cropland burning into a global fire model. However, because pasture has not been mapped by satellite as cropland has, no global estimates of pasture burning have ever been produced. This means that estimates of pasture and non-agricultural fire are entangled in global data sets, and thus observations have not distinguished what may be important differences in fire regime. To understand the total effect of agricultural management on fire occurrence, then, the scientific community must go beyond estimates of cropland burned area and associated emissions.

The work presented here is an effort to bridge these gaps in our knowledge. We present a method that uses fire observations in conjunction with estimates of land-use distribution to statistically estimate the amount of fire associated with cropland, pasture, and other lands at global and regional scales. In addition to examining the total area of such burning, the same method is used to investigate patterns of associated carbon emissions.

\section{Methods}

\subsection{Analytical technique}

Magi et al. (2012) analyzed seasonal patterns of agricultural burning (i.e., combined cropland and pasture) from nonagricultural burning using estimates of land-use distributions and satellite-derived fire data. This study builds upon the methods presented by Magi et al. (2012), differentiating between cropland, pasture, and other burning and generating estimates of the amount of each type of fire in terms of both burned area and carbon emissions.

The total amount of burned area in some grid cell $i\left(B_{i}\right)$ can be represented as the sum of the burned area on each land-use type $k$. This can in turn be represented as the product of the area of that land cover type in the grid cell $\left(A_{k, i}\right)$ and the fraction of that land-use type that burned in that grid cell $\left(F_{k, i}\right)$ :

$B_{i}=F_{\mathrm{c}, i} A_{\mathrm{c}, i}+F_{\mathrm{p}, i} A_{\mathrm{p}, i}+F_{\mathrm{o}, i} A_{\mathrm{o}, i}$,

where the subscripts c, p, and o refer to cropland, pasture, and other land, respectively. The values of each $F_{k, i}$ are unknown, but a best-guess $\widehat{F}_{k}$ can be estimated across a group 
of $N$ grid cells:

$\left[\begin{array}{c}B_{1} \\ B_{2} \\ \vdots \\ B_{i} \\ \vdots \\ B_{N}\end{array}\right]=\left[\begin{array}{ccc}A_{\mathrm{c} 1} & A_{\mathrm{p} 1} & A_{\mathrm{o} 1} \\ A_{\mathrm{c} 2} & A_{\mathrm{p} 2} & A_{\mathrm{o} 2} \\ \vdots & \vdots & \vdots \\ A_{\mathrm{ci}} & A_{\mathrm{pi}} & A_{\mathrm{o} i} \\ \vdots & \vdots & \vdots \\ A_{\mathrm{c} N} & A_{\mathrm{p} N} & A_{\mathrm{o} N}\end{array}\right] \times\left[\begin{array}{c}\widehat{F_{\mathrm{c}}} \\ \widehat{F_{\mathrm{p}}} \\ \widehat{F}_{\mathrm{o}}\end{array}\right]+\left[\begin{array}{c}\epsilon_{1} \\ \epsilon_{2} \\ \vdots \\ \epsilon_{i} \\ \vdots \\ \epsilon_{N}\end{array}\right]$

$\boldsymbol{B}=\mathbf{A} \widehat{\boldsymbol{F}}+\boldsymbol{\epsilon}$

where $\epsilon_{i}$ is the residual for grid cell $i$. The set of $\widehat{F}_{k}$ values that minimize the sum of squared errors across a large number of grid cells can be calculated using

$\widehat{\boldsymbol{F}}=\left(\mathbf{A}^{\top} \mathbf{A}\right)^{-1} \mathbf{A}^{\top} \boldsymbol{B}$,

where $\mathbf{A}$ and $\boldsymbol{B}$ are observations of land-use distributions and burned area, respectively. We have observed that a number of $\widehat{F}_{k}$ values are found to be negative. This has two possible interpretations. One is that negative $\widehat{F}_{k}$ values are simply a statistical artifact of the analysis without physical meaning, and that such lands burn either very little or not at all. The other possibility is that negative $\widehat{F}_{k}$ values represent a real aspect of fire occurrence: namely, that the negative influence of such land covers on other land covers outweighs any fire happening on the land cover itself. This could be considered to represent either active suppression to protect high-value land such as crop fields, and/or to reflect the widely documented role of anthropogenic land covers (especially cropland) in fragmenting the burnable landscape (Archibald et al., 2009; Andela and van der Werf, 2014; Hantson et al., 2015).

For the purposes of illustration, consider a hypothetical grid cell for which the analysis estimates $5 \mathrm{~km}^{2}$ of burned area for cropland:

$\widehat{F_{\mathrm{c}}} A_{\mathrm{c}, i}=5$,

$B_{i}=\widehat{F}_{\mathrm{c}} A_{\mathrm{c}, i}+\widehat{F}_{\mathrm{p}} A_{\mathrm{p}, i}+\widehat{F}_{\mathrm{o}} A_{\mathrm{o}, i}$

A different grid cell with equal $\widehat{F}_{k}$ values and twice the area of cropland but the same amounts of pasture and other land would have $5 \mathrm{~km}^{2}$ more burning estimated:

$\widehat{F_{\mathrm{c}}}\left(2 A_{\mathrm{c}, i}\right)+\widehat{F}_{\mathrm{p}} A_{\mathrm{p}, i}+\widehat{F}_{\mathrm{o}} A_{\mathrm{o}, i}=B_{i}+\widehat{F}_{\mathrm{c}} A_{\mathrm{c}, i}=B_{i}+5$.

The same logic shows that there would be less fire in the second grid cell if $\widehat{F}_{\mathrm{c}}$ were negative.

Conversely, $\widehat{F}_{k}$ values could also incorporate positive effects of one land-use type on the others. For example, much of the fire observed in the frontier of the Amazon rainforest is associated with land management burning that escapes into surrounding forest (Uhl and Buschbacher, 1985; Cochrane
Table 1. List of GFED regions and abbreviations (Giglio et al., 2006).

\begin{tabular}{ll}
\hline Abbreviation & Full name \\
\hline BONA & Boreal North America \\
TENA & Temperate North America \\
CEAM & Central America \\
NHSA & Northern Hemisphere South America \\
SHSA & Southern Hemisphere South America \\
EURO & Europe \\
MIDE & Middle East \\
NHAF & Northern Hemisphere Africa \\
SHAF & Southern Hemisphere Africa \\
BOAS & Boreal Asia \\
CEAS & Central Asia \\
SEAS & Southeast Asia \\
EQAS & Equatorial Asia \\
AUST & Australia and New Zealand \\
\hline
\end{tabular}

and Schulze, 1998). The $\widehat{F}_{\mathrm{c}}$ and $\widehat{F}_{\mathrm{p}}$ values in that region could potentially account for this effect as well. In this conceptualization, then, $\widehat{F}_{k}$ values should be interpreted not as "the fraction of land use $k$ that burns across the region" but rather as "the net effect of land use $k$ on fire in the region, expressed as a fraction of the area of land use $k$ in the region". That is, for every additional unit area of land use $k$, we expect $\widehat{F}_{k}$ more (if $\widehat{F}_{k}>0$ ) or fewer (if $\widehat{F}_{k}<0$ ) units of burning.

To clarify, imagine a region with $2000 \mathrm{~km}^{2}$ of cropland, $3000 \mathrm{~km}^{2}$ of pasture, and $5000 \mathrm{~km}^{2}$ of other land. For some month, this region has $\widehat{F}_{\mathrm{c}}=-0.1, \widehat{F}_{\mathrm{p}}=0.2$, and $\widehat{F}_{\mathrm{o}}=0.1$. The associated burned area values would be $2000 \times-0.1=$ $-200 \mathrm{~km}^{2}$ for cropland, $3000 \times 0.2=600 \mathrm{~km}^{2}$ for pasture, and $5000 \times 0.1=500 \mathrm{~km}^{2}$ for other land, for a total of $900 \mathrm{~km}^{2}$ of burning across the region. Now imagine another region that is identical except that it contains an extra $1000 \mathrm{~km}^{2}$ of cropland. This new region would have $3000 \times$ $-0.1=-300 \mathrm{~km}^{2}$ of burned area associated with cropland, for a total of $800 \mathrm{~km}^{2}$ of burning across the region. The interpretation of negative cropland-associated burned area is not that some actual negative area is burning somehow but rather that, however much cropland is burning, it is preventing so much fire on pasture and/or other land that its net influence on fire in the region is negative.

The results presented in this study are explored in the main text with this latter interpretation of $\widehat{F}_{k}$ values in mind. Equivalent figures in the Supplement show results with $\widehat{F}_{k}$ restricted to positive values, essentially interpreting $\widehat{F}_{k}$ values as "the fraction of land use $k$ that burns across the region".

To account for temporal variability in the total amount of fire and its distribution among different land-use types, the analysis is performed separately for each month and year. Fire patterns and practices also vary across space, so each of 132 regions is analyzed separately. This set of regions (Fig. 1) was created with the goal of minimizing within- 


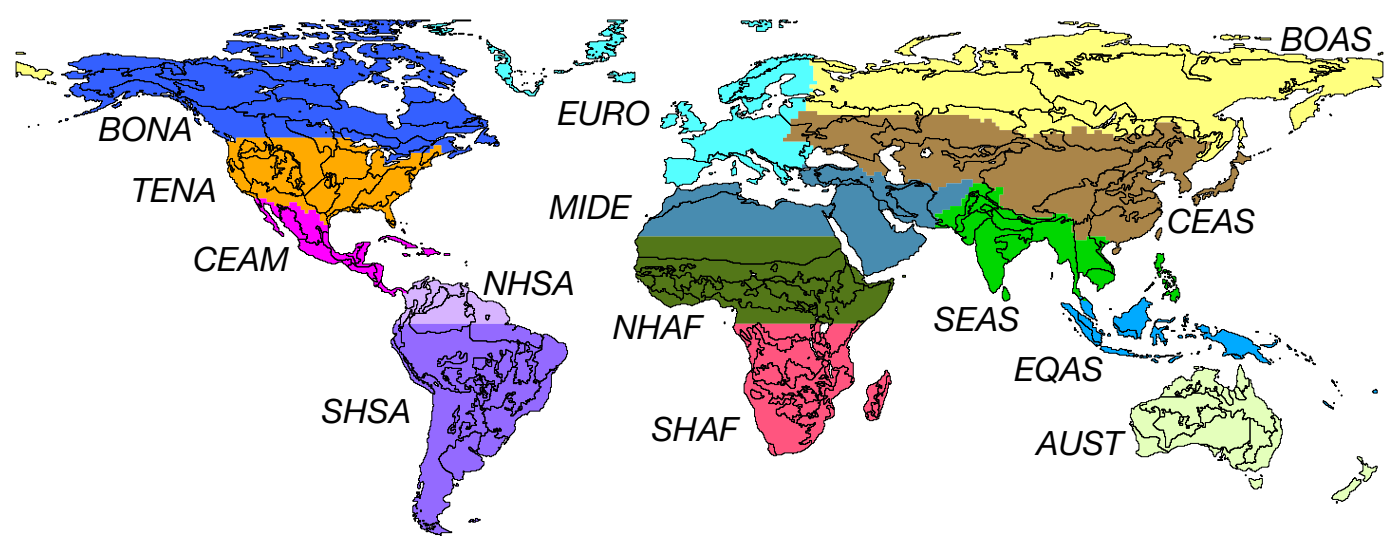

Figure 1. Regions used for analysis (outlines) overlaid on GFED regions (colors and labels; Giglio et al., 2006). See Table 1 for abbreviations. Shapefile with analysis regions available in the Supplement.

region heterogeneity in terms of climate, biome, and fire extent and timing, while still including enough grid cells to ensure an adequate sample size for estimation. The final region set resulted from an iterative process whereby we performed the analysis for a candidate region set, noted areas of severe under- or overestimation, drew new region boundaries, and re-ran the analysis. The Terrestrial Ecosystems of the World map (Olson et al., 2001), agricultural distribution maps (Klein Goldewijk et al., 2010), and observations of fire extent and timing (Randerson et al., 2012) guided development of the regions map. For example, regions were designed to avoid containing multiple patches of high concentration of a land use that appeared to vary widely in seasonal timing or amount of fire. As in Magi et al. (2012), the 14 regions developed for the Global Fire Emissions Database (Giglio et al., 2006) are used to structure the discussion of the results presented here (Fig. 1, Table 1). For clarity, these will be referred to as the "GFED regions" to distinguish them from the 132 "analysis regions". In all, $4752 \widehat{F}_{k}$ values are estimated per year ( 3 land-use types $\times 12$ months $\times 132$ analysis regions) from 2001 to 2009 . A shapefile containing the analysis regions for use in GIS software can be found in the Supplement.

Some restrictions were imposed on the analysis. Any landuse type whose prevalence across a region during a given year was on average less than $5 \%$ was excluded, with the $\widehat{F}_{k}$ value for such land cover types taken to be zero, to avoid issues of near-singularity in the matrix calculations. Also, for region-months with no observed fire, all $\widehat{F}_{k}$ values were assumed to be zero.

\subsection{Input data}

\subsubsection{Burned area and fire emissions}

Observations of monthly burned area and carbon emissions at $0.25^{\circ}$ resolution were obtained from the GFED3s data set (Randerson et al., 2012). Based on the Global Fire Emis- sions Database version 3 (GFED3; Giglio et al., 2010; van der Werf et al., 2010), GFED3s was designed to improve detection of small fires by incorporating an estimate of burned area based on detections of active fires outside observed fire scars. This algorithm produces an estimate of annual burned area $35 \%$ higher than the Collection 5 MCD64A1 burned area product, which was produced using the same algorithm as most of the GFED3 data, across the time period of its coverage (2001-2010), with several large regions seeing their burned area estimates more than double (Randerson et al., 2012). Nearly a fifth of that increase occurred in croplands and cropland-natural vegetation mosaic, the estimated burned area of which increased by 123 and 79\%, respectively. Moreover, about a third occurred in savannas and grasslands, which could feasibly serve as pasture (Randerson et al., 2012). Results for cropland influence on burned area from this analysis are compared to GFED3s estimates of burned area on cropland as well as "cropland-natural mosaic", which is defined as land with "a mosaic of croplands, forests, shrubland, and grasslands in which no one component comprises more than $60 \%$ of the landscape" (Friedl et al., 2002).

GFED3s estimates of fire-related emissions were generated, as for the original GFED3 data set (van der Werf et al., 2010), by coupling the burned area observations for each land-use type with a climate-driven vegetation model (Randerson et al., 2012). Biome-specific emissions factors combined with biomass estimates from the vegetation model then produced the amount of emissions per area burned. The analytical technique described in Sect. 2.1 can be as easily applied to emissions as it can to burned area, in which case the $\widehat{F}_{k}$ values represent the net effect per square kilometer of each land-use type on fire emissions. Here, an analysis of emissions of carbon-containing compounds was conducted in parallel with the analysis of burned area. A breakdown of GFED3s carbon emissions by land cover type, such as was provided for burned area, was not available. 


\subsubsection{Land use}

Data on area of cropland and pasture were taken from an annualized version of the History Database of the Global Environment version 3.1 (HYDEv3.1), described by Klein Goldewijk et al. (2010). This public data set, available at $5 \mathrm{~min}$ spatial resolution, is the basis for the historical part of the standardized gridded land-use transitions reconstructions (Hurtt et al., 2011) used in the Coupled Model Intercomparison Project, phase 5 (Taylor et al., 2012). The publicly available data are only produced for every 5 years during the recent past, but K. Klein Goldewijk provided annual estimates for the period 2000-2009 (K. Klein Goldewijk, personal communication, 2012). Distributions are assumed to not change within years. The amount of "other" ("nonagricultural") land is calculated as the fraction of land not classified as cropland or pasture. Maps of the mean land cover distributions from HYDE for 2001-2009 can be found in Fig. S1 in the Supplement.

Grazing land can take many different forms, including both planted forage species and naturally occurring species (often referred to as rangeland). Data from the Food and Agriculture Organization (FAO) were used in compiling maps of present-day land use in HYDE; HYDE's pasture data is based on the FAO's “permanent meadows and pastures" (Klein Goldewijk et al., 2007). These are defined as lands "used permanently (five years or more) to grow herbaceous forage crops, either cultivated or growing wild (wild prairie or grazing land)" (FAO, 2005). The term "pasture" is thus used throughout this paper in this broad land-use sense. Note, however, that this is distinct from any given land cover type, such as grassland or savanna - that is, all pasture has herbaceous vegetation, but not all land with herbaceous vegetation is necessarily pasture.

\subsubsection{Spatiotemporal coverage and resolution}

All analyses were performed at the native resolution of GFED3s, $0.25^{\circ}$, with HYDE land-use data being downscaled to match. The analysis covered the period 2001-2009, as HYDE data for 2010 were not available.

\section{Results}

\subsection{Fire extent}

Every year, nearly half of all burned area is associated with agricultural lands (Fig. 2a): pasture contributes $203 \mathrm{Mha} \mathrm{yr}^{-1}$ of burned area, while cropland accounts for $21 \mathrm{Mha} \mathrm{yr}^{-1}$. Non-agricultural lands are associated with $243 \mathrm{Mhayr}^{-1}$ of burned area. Overall, the analysis slightly overestimated total global annual burned area, giving 467.6 $\mathrm{Mha} \mathrm{yr}^{-1}$ instead of $466.9 \mathrm{Mha} \mathrm{yr}^{-1}(+0.2 \%$ error $)$.

The distribution of fire emissions across land-use types differs strongly from what might be expected based on their
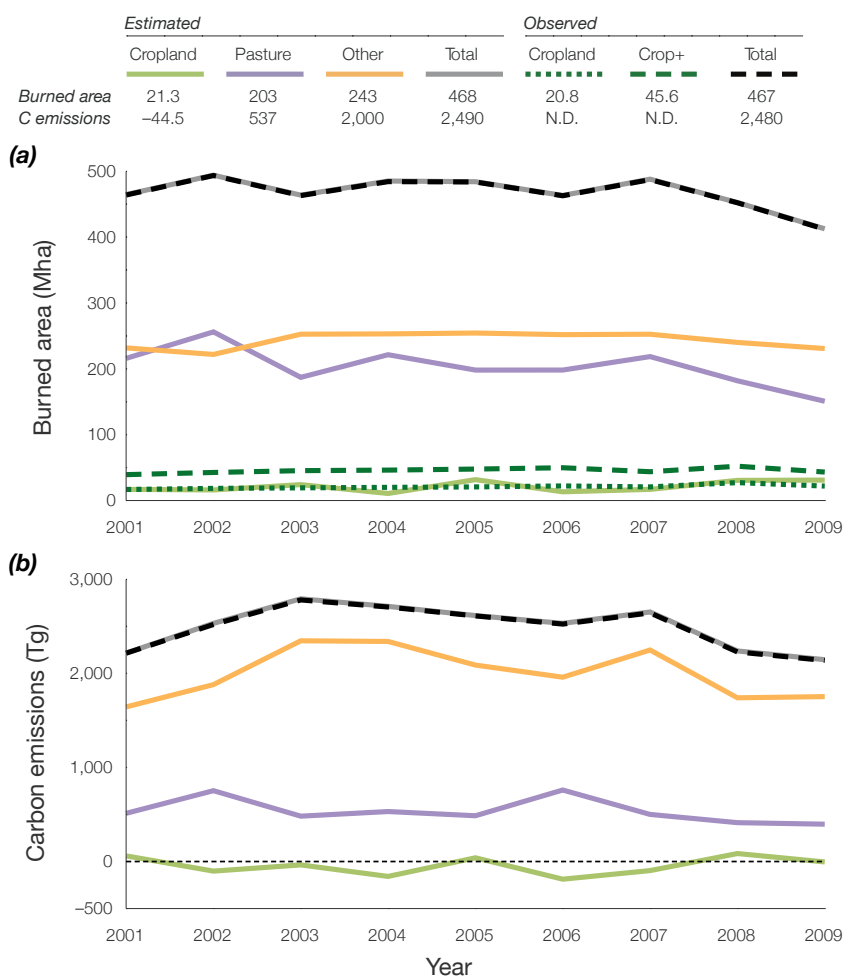

Figure 2. Observed and estimated annual time series of net observed and estimated global burned area (a; Mha) and C emissions $(\mathbf{b} ; \mathrm{Tg}=\mathrm{Mt})$. Numbers in table represent annual means. "N.D.": no data; "Crop+": cropland + cropland-natural mosaic. Corresponds to Fig. S2.

relative burned areas. Whereas annual burned area associated with non-agricultural land was only $\sim 20 \%$ greater than that with pasture, non-agricultural land was responsible for over $260 \%$ more fire C emissions (Fig. 2b). Emissions per area burned can be thought of as the product of fuel load and combustion completeness - i.e., the amount of dead and living biomass multiplied by the fraction combusted (Seiler and Crutzen, 1980). Fuel load should be higher on average for non-agricultural lands than for pasture because pastures do not have trees in densities comparable to more carbonrich forest ecosystems. Moreover, although croplands had a net positive contribution to global burned area, they had a net negative effect on fire emissions (Fig. 2). This suggests that, even though less area would have burned with less cropland, the burning would be happening in more carbon-dense ecosystems. As with burned area, total global fire emissions were very slightly overestimated (by less than $0.4 \%$; Fig. 2b).

Figure 3 shows time series plots as in Fig. 2 but broken down by GFED region. Pasture can be seen to account for a sizable portion of burning in South America (NHSA and SHSA), Africa (NHAF and SHAF), central Asia (CEAS), and Australia (AUST). Overall, the algorithm reproduces the amount and interannual variability of total fire well at these 
(a)
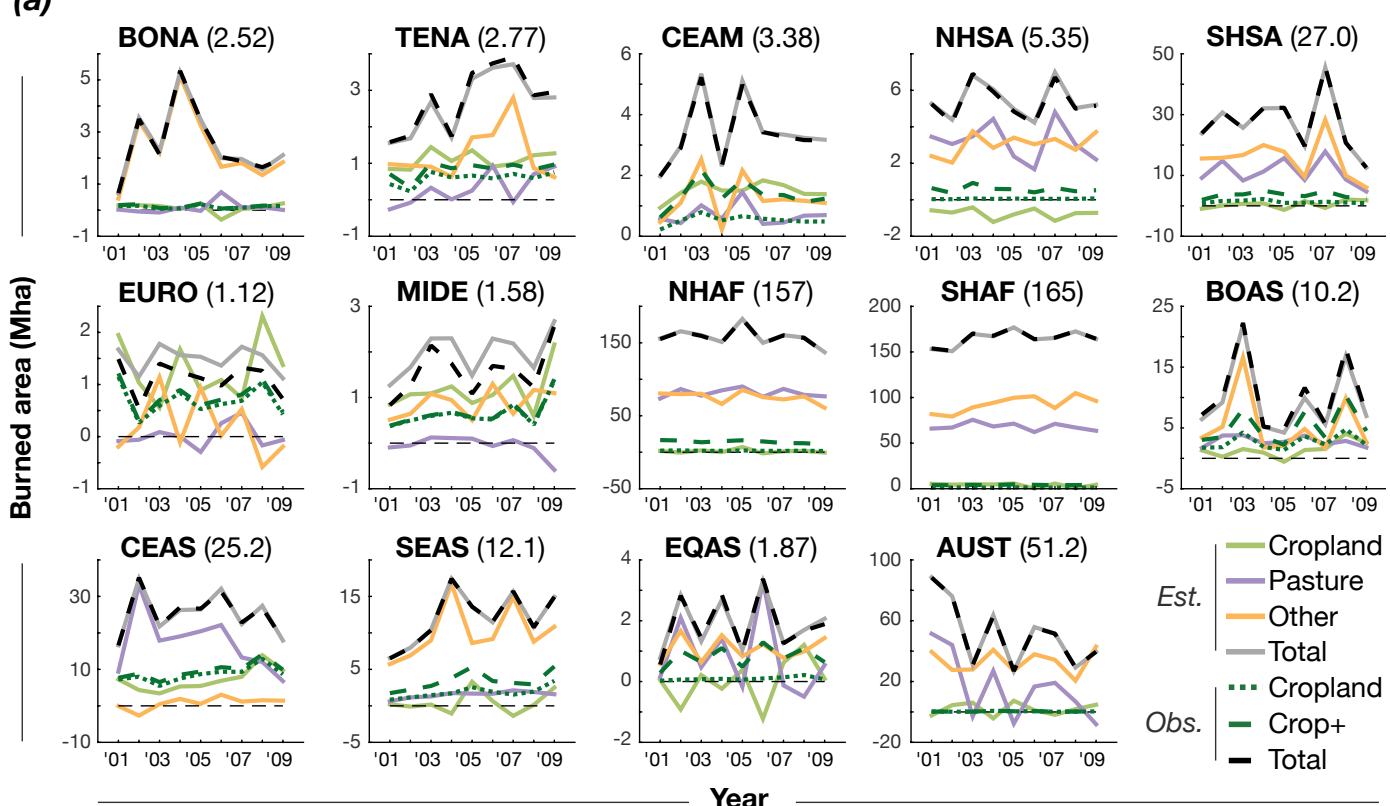

(b)
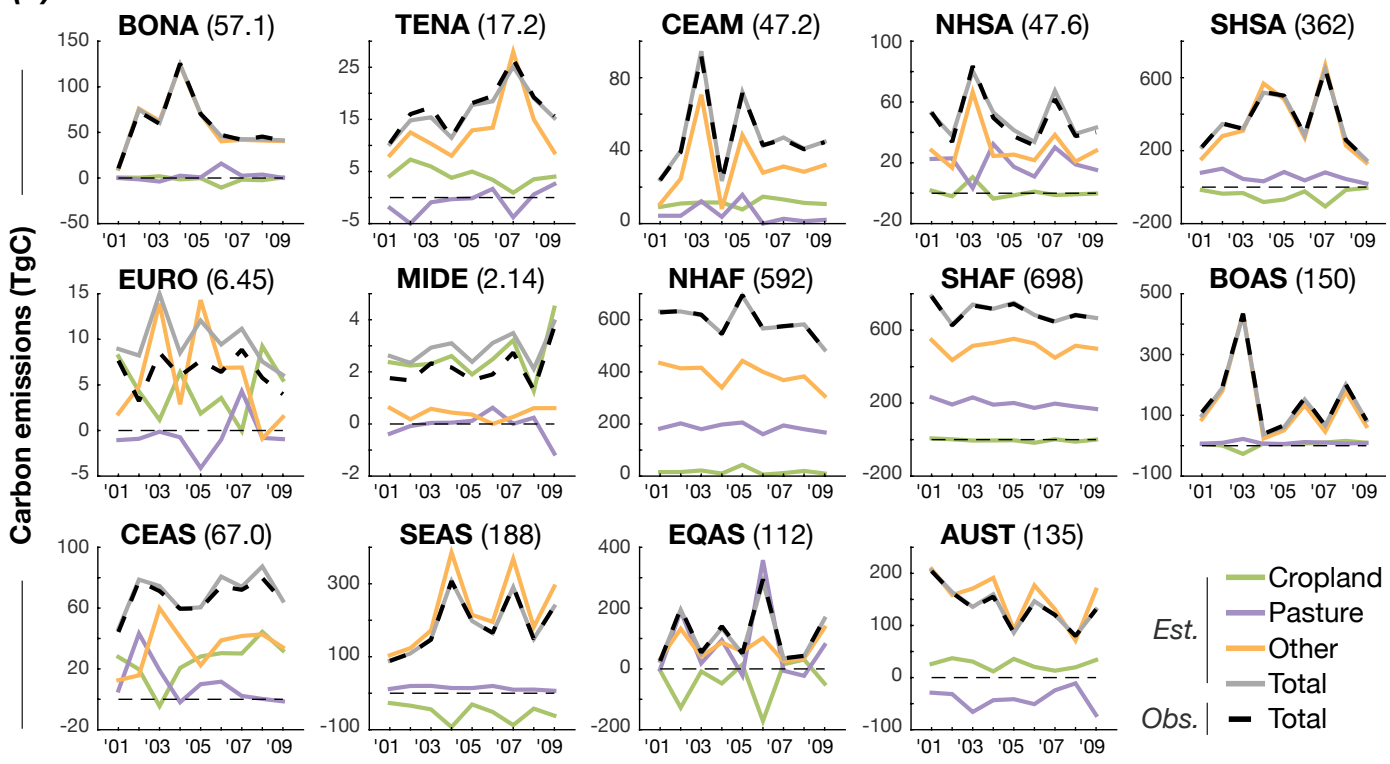

\begin{tabular}{c|l} 
Est. & $\begin{array}{l}\text { - Cropland } \\
\text { - Pasture } \\
\text { - Other } \\
\text { - Total }\end{array}$ \\
Obs. $\mid$ & - Total
\end{tabular}

Year

Figure 3. Annual time series of different fire types in each GFED region based on analysis of burned area (a; Mha) and C emissions (b; $\mathrm{TgC}$ ). Numbers in parentheses next to region names represent mean annual observed fire there (either burned area or C emissions). "Crop+": cropland + cropland-natural mosaic. Corresponds to Fig. S3. Data available in the Supplement.

large regional scales: on a scatterplot comparing the estimated and observed burned area of the 1512 GFED regionmonths (14 regions $\times 108$ months), most points fall near the one-to-one line (linear regression $y$ intercept $=-3.7 \times 10^{-3}$, slope $=1.0008$, Pearson's $r=0.9997$; Fig. S4). The most apparent discrepancies compared to GFED3s occur in Europe (EURO) and the Middle East (MIDE), whose mean annual burned area totals are underestimated by $\sim 40$ and $\sim 30 \%$, respectively. With respective mean annual observed burned areas of $\sim 11200$ and $\sim 15800 \mathrm{~km}^{2}(0.2$ and $0.3 \%$ of global fire activity), however, these are the least-burned GFED regions.

The net mean annual burned area associated with croplands, pasture, and other land is illustrated in the maps in Fig. 4. Pasture accounts for a large amount of burned area in the savannas of NHAF and SHAF, with NHSA, SHSA, 


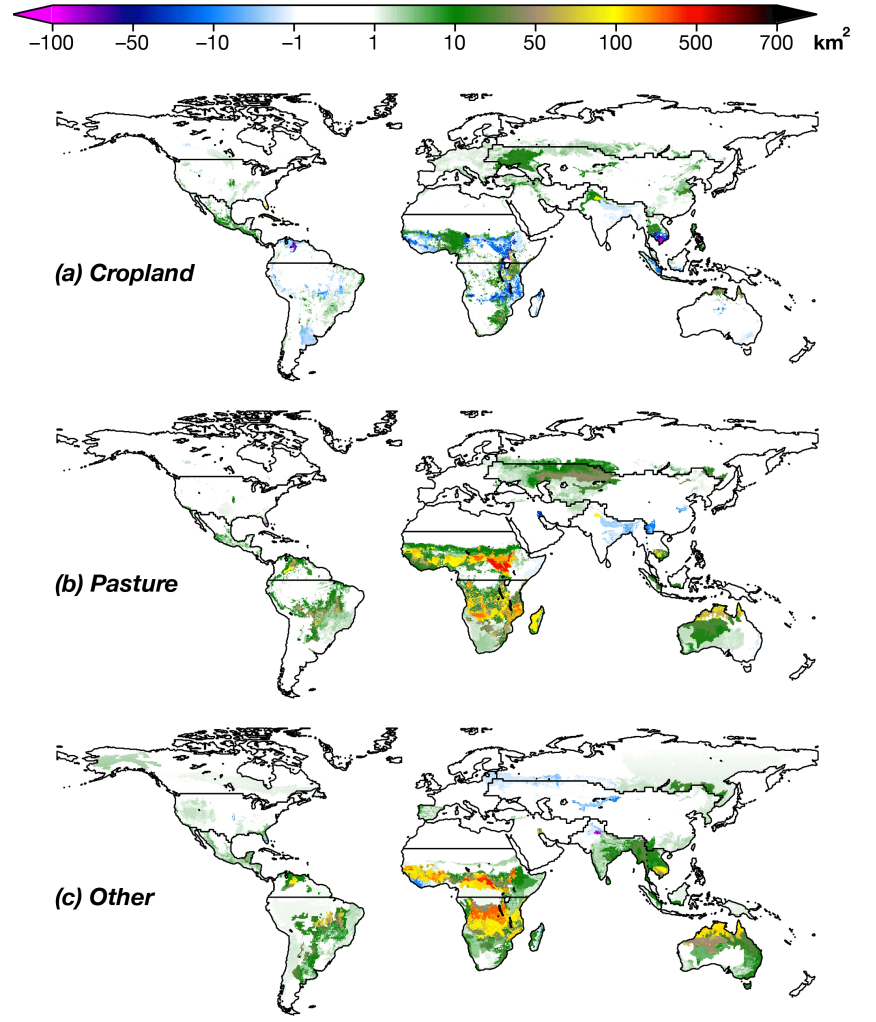

Figure 4. Maps of mean annual burned area $\left(\mathrm{km}^{2}\right)$ associated with (a) cropland, (b) pasture, and (c) other land. These are calculated from monthly maps generated by the equation $B_{i}=\widehat{F_{k}} A_{k, i}$ for each month and region. The results can be interpreted as how much more (or less) fire would be expected if the area of the given land cover were to double (and the others remain the same). Corresponds to Fig. S5. Compare with seasonal maps in Figs. S8-S11.

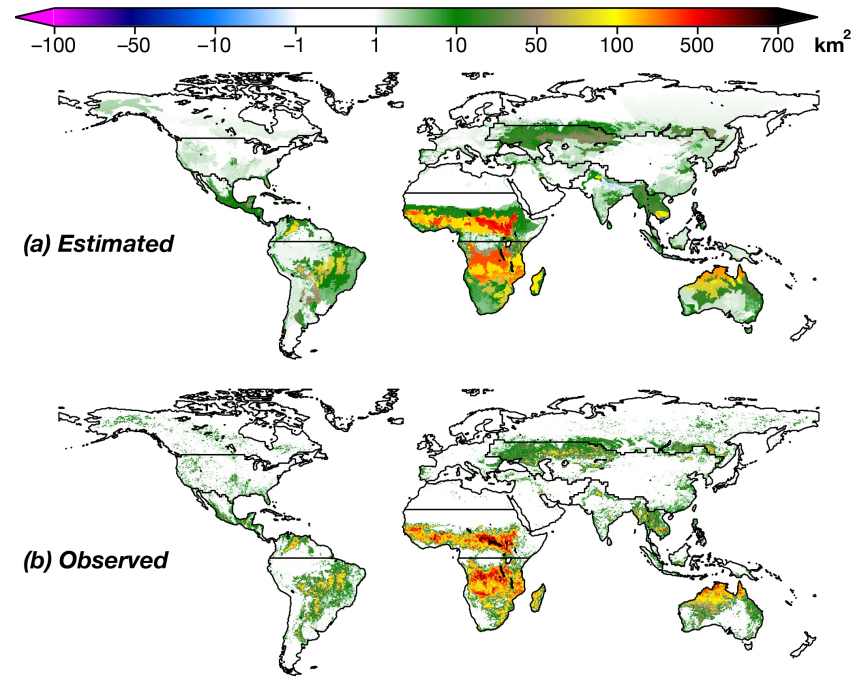

Figure 5. Maps of net mean annual total burned area $\left(\mathrm{km}^{2}\right)$ : (a) estimated and (b) observed. Corresponds to Fig. S6 in the Supplement.
CEAS, and AUST being highlighted to a lesser degree. Eastern Europe, northern Australia, various parts of sub-Saharan Africa, and especially India's Punjab state emerge as spots where cropland has a strong positive effect on burned area (Fig. 4a). Cropland has a net negative effect on burned area in other places - most notably Cambodia and southern Vietnam, Ethiopia and South Sudan, India, eastern Argentina, and southeastern Australia. These are mostly biomes where vegetation tends to be quite fire-prone, and thus where strong active and/or passive suppression due to cropland might be expected. Interestingly, pasture and non-agricultural lands are also seen to sometimes have net suppressive effects (Fig. 4b and c). In the case of pasture, this could be due to a passive effect - grazing pressure can reduce fuel loads, leading to slower-spreading and/or less-frequent fires (Cheney and Sullivan, 2009). Non-agricultural lands with net negative influence may result from either active or passive suppression. People might use alternative management techniques to avoid fire use on cropland or pasture near valuable or protected forests, for example. Alternatively, if fire on pasture is at least to some extent unmanaged, less-flammable vegetation types such as forest or wetland could serve to break up pasture into disconnected patches and thus reduce how much it can burn. It is also important to remember that apparent negative influences might not represent any real process, being instead artifacts of this analysis (see figures in the Supplement). Overall, the algorithm generates maps of total fire that broadly agree with the distribution of burning seen in the observations (Fig. 5). However, the spatial variation in burned area within regions is not fully captured; we discuss this further in Sect. 4.3.

\subsection{Fire timing}

The previous results have shown the influence of different land-use types on fire at an annual level, but land use and management can also affect the seasonality of fire. Figure 6 shows, for each GFED region, the mean seasonality of estimated and observed burned area and carbon emissions as compared with observations. As expected based on the algorithm's performance with regard to annual total fire (Fig. 3), all regions except EURO and MIDE show good correspondence between observations and estimates of total fire.

Estimated cropland fire is sometimes higher or lower than GFED3s for cropland or cropland-natural mosaic. One reason for this is that the analysis may describe the net effect of cropland on fire, as discussed above. Another is that detection of cropland, especially of small fields, is difficult using moderate-resolution satellite imagery, such as the MODIS MCD12 data set used in GFED3s (Friedl et al., 2010). Klein Goldewijk et al. (2007), for example, had to deal with this in developing HYDE. In some regions - such as the contiguous 48 United States (a.k.a. temperate North America, TENA), Europe (EURO), and central Asia (CEAS) - trends of estimated cropland burned area closely follow 
(a)
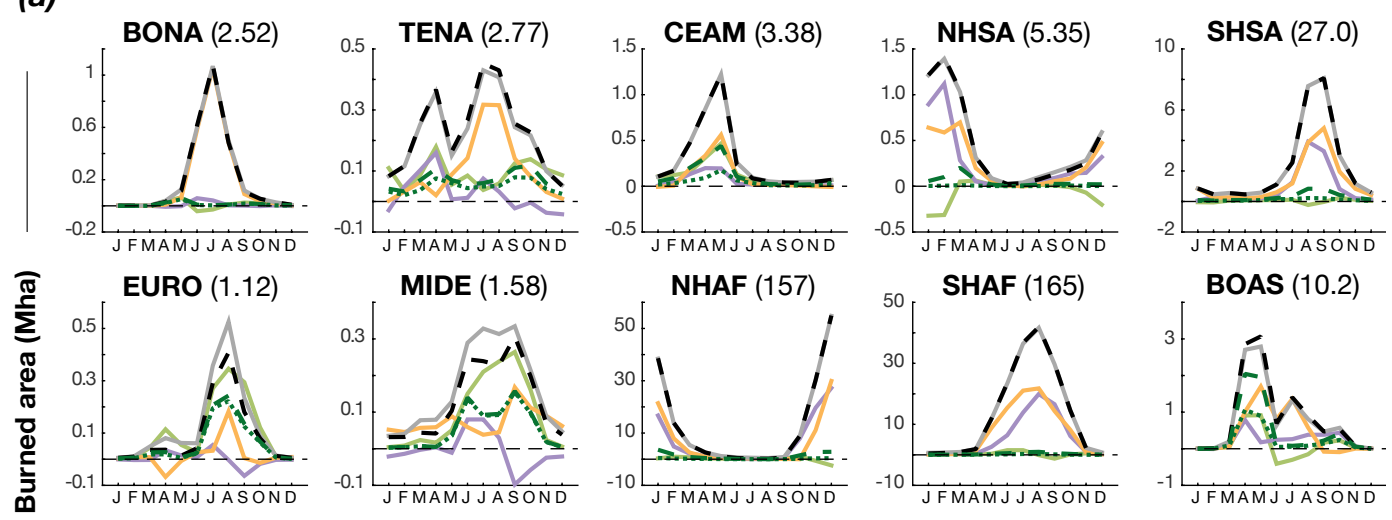

BOAS (10.2)
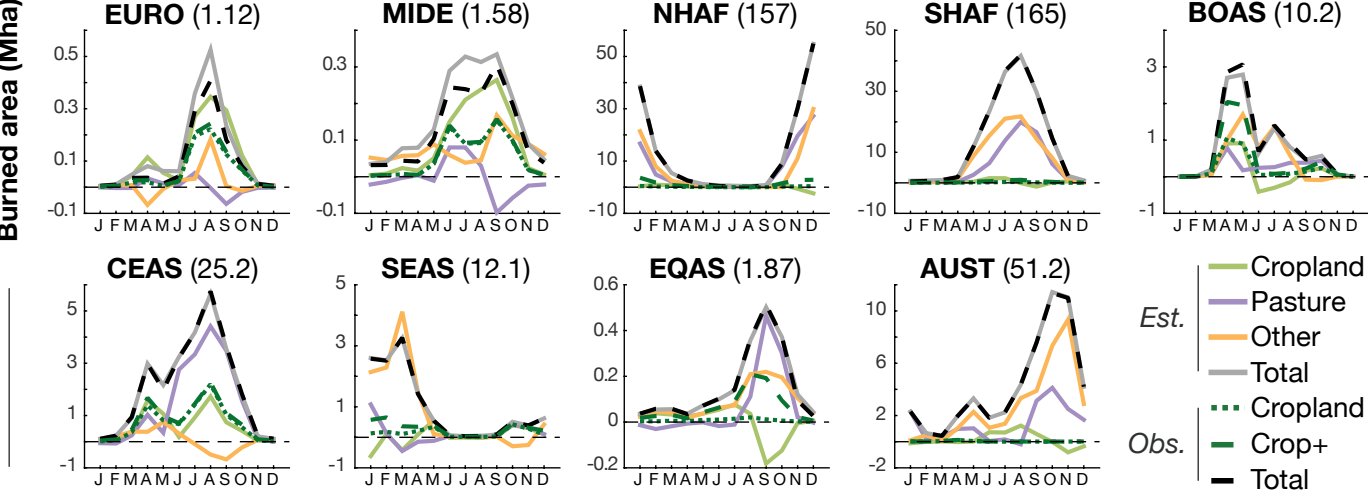

(b)
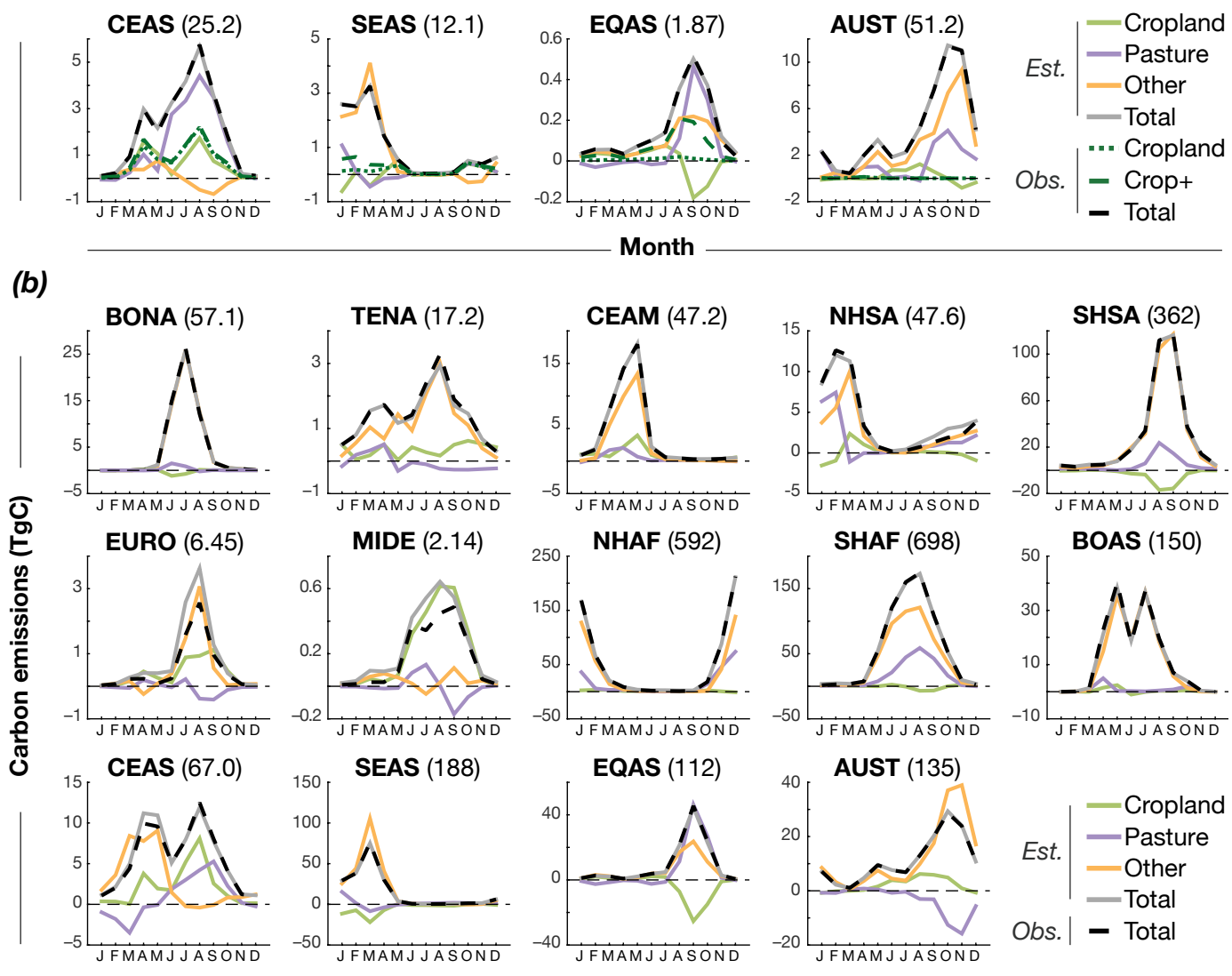

Month
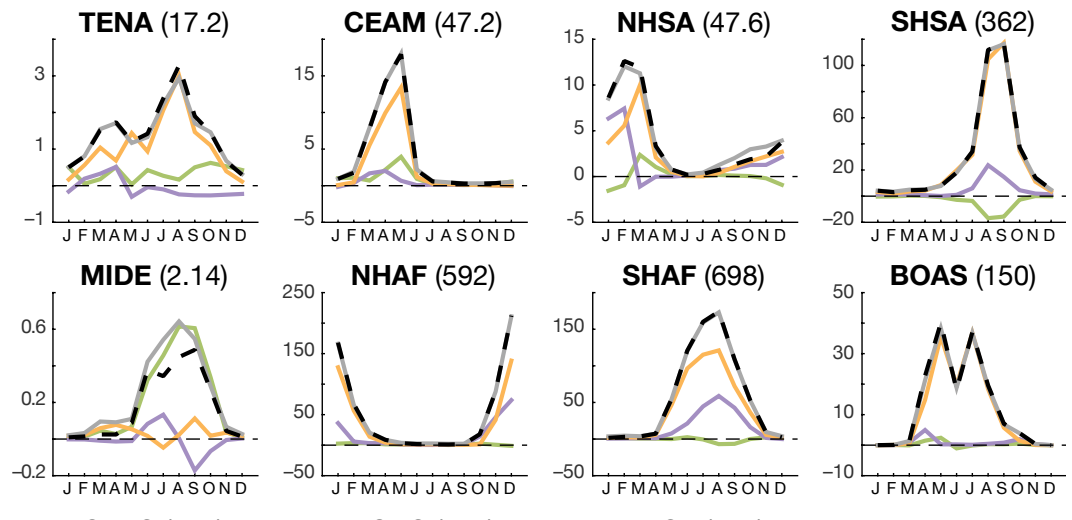

SEAS (188)
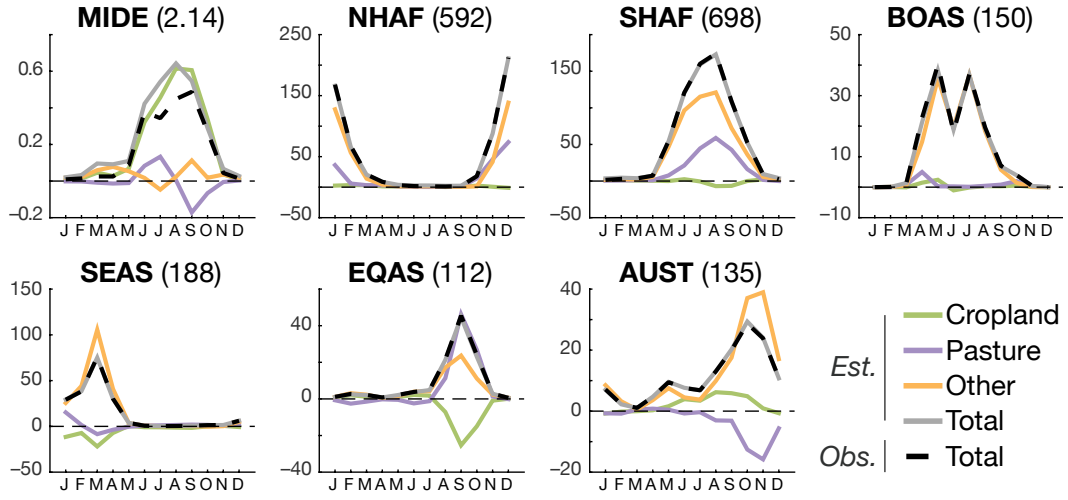

Month

Figure 6. Seasonality of different fire types in each GFED region based on analysis of burned area (a; Mha) and C emissions $(\mathbf{b} ; \mathrm{TgC})$. Numbers in parentheses next to region names represent mean annual observed fire there (either burned area or $\mathrm{C}$ emissions). Corresponds to Fig. S7. Data available in the Supplement.

those from observations (Fig. 6). In other regions - such as Northern Hemisphere South America (NHSA) and equatorial Asia (EQAS) - cropland has an apparent negative influence on burned area for several months of the year. A comparison with observed cropland burning (of which there is little in such months) suggests that this is often a nearly pure signal of a suppressive effect. The effect appears especially strong in EQAS during September and October, although the large amount of cropland-natural mosaic burning complicates interpretation there. Pasture sometimes has a similar effect, although rarely; this is most apparent in TENA, EURO, MIDE, and SEAS. In EURO and CEAS, even other lands sometimes have a net negative estimated burned area. As discussed above, negative influence of pasture and nonagricultural lands could reflect active and/or suppressive effects associated with these land-use/cover types. 

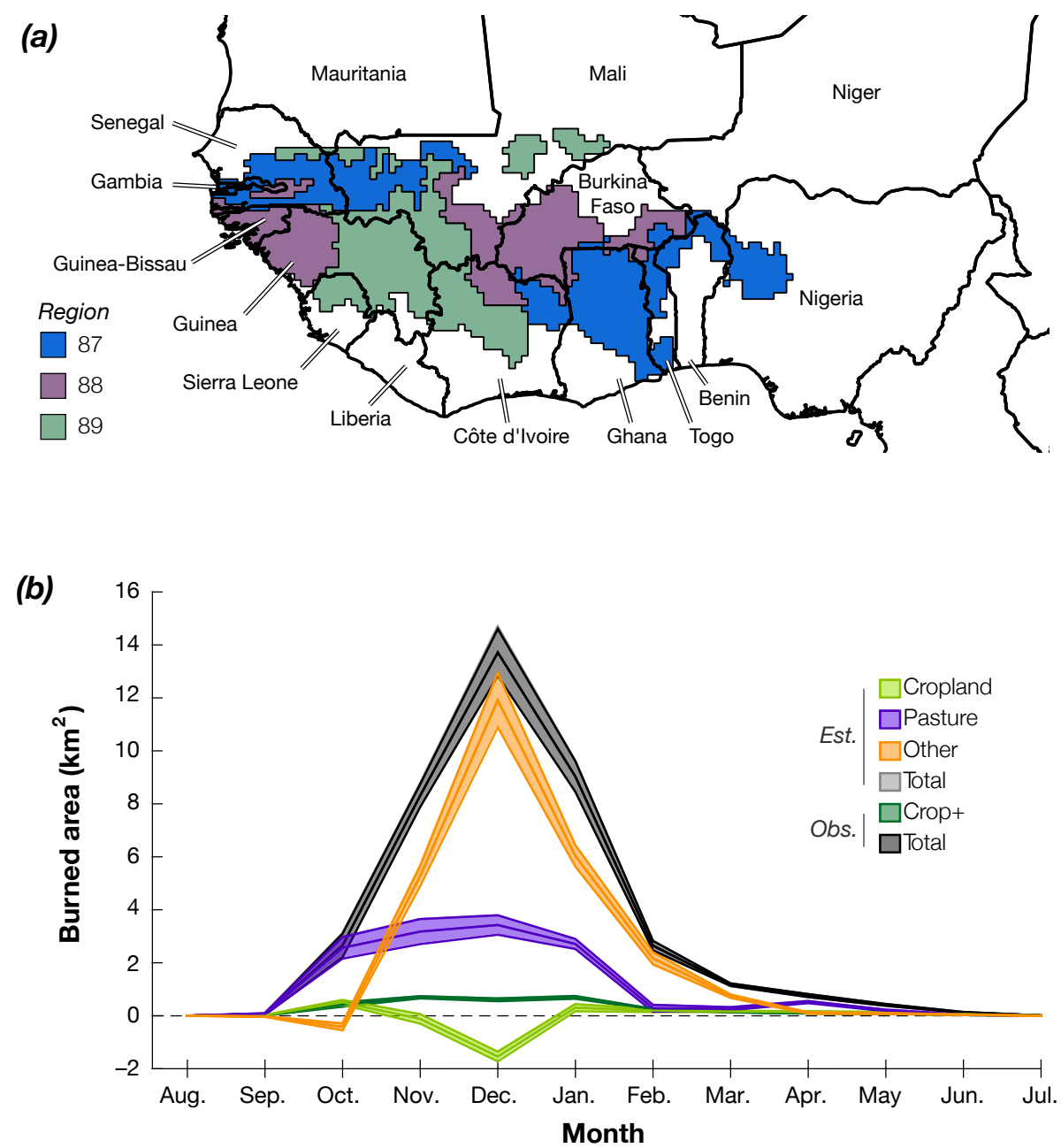

Figure 7. (a) Area included in the West African case study, color-coded by analysis region. (b) Mean seasonality of burned area in case study regions. Shading represents interannual variability ( \pm 1 SEM). Note that the $x$ axis begins in August. Corresponds to Fig. S12.

Figures S8-S11 present another way to examine the seasonal changes in the influence of different land covers on burning. This presents an advantage over the regional time series discussed above where contrasting patterns exist within one GFED region. For example, Fig. S9a shows that cropland is contributing to burned area in southwestern Australia from March to May, but is suppressing fire in the northern part of the continent. Figure 6 does not capture this pattern, instead making it appear as though cropland has no effect across the entire region of Australia and New Zealand (AUST).

The effect of different land uses on fire can be best explored and understood by examining patterns across a few regions. The savannas of western Africa have seen a good deal of remote sensing, anthropological, and ecological research regarding their fire regimes and thus provide a good example. The Sudanian savanna there experiences a distinct dry season from approximately October or November through April or May, during which it burns extensively (Laris, 2002;
Kull and Laris, 2009). The fire regime is highly managed by people for agriculture and other purposes, with burning generally initiated early in the dry season and suppressed later. Early fires can have a number of benefits. For example, burning that occurs while the soil still has some residual moisture allows herbaceous regrowth, replenishing food availability for livestock ahead of the worst of the dry season (Mbow et al., 2000). Due to higher fuel moisture, these fires are also often easier to control than more intense burns under more flammable conditions later in the dry season. People often burn savanna early to fragment the burnable landscape, preventing late-season burns that can damage property and resources (Laris, 2002).

We isolated three regions (Fig. 7a) that mostly fall into the ecoregions "West Sudanian savanna" and "Guinean forestsavanna mosaic" according to Olson et al. (2001). Small amounts of other land cover types - including lowland and montane forests, flooded savanna, and Sahelian acacia savanna - are also included. On average, this area sees a slight 
negative annual contribution of cropland to burned area - that is, cropland tends to reduce the amount of burning on pasture and other lands. Pasture contributes over a third of the observed annual burned area, with non-agricultural lands accounting for approximately twice that. Observed total burned area, which is matched almost perfectly by the estimate, peaks with pasture and non-agricultural burning in December (Fig. 7). As expected based on the literature on human fire management practices in this region (Mbow et al., 2000; Laris, 2002), most fire associated with pasture and non-agricultural land occurs in the early dry season - i.e., before January. Interestingly, though, the fire season for pasture seems to begin and end about a month earlier than that of non-agricultural land: from about October through January instead of November through February. Although early fire is often beneficial for all savanna in the region, the added impetus of burning early to create food for livestock appears to result in a distinct pattern. However, it is also possible that the October burning represents intentional burning of short-grass savanna, which is not actually used by livestock but may have been considered "pasture" in the land-use data (P. Laris, personal communication, 2015). An overall net suppressive effect of cropland is also evident. The strongest negative influence corresponds with both the December peak of noncropland fire and the harvest (P. Laris, personal communication, 2015; Figs. 7b, S8-S11). This emerges despite the fact that at least some cropland burning (including croplandnatural mosaic) was observed throughout the dry season (Fig. 7b). Even though there is some observed fire associated with cropland, then, there would be much more if cropland were replaced with pasture or non-agricultural land. This interpretation has assumed that negative values are meaningful, but similar patterns emerge using constrained $\widehat{F}_{k}$ values (Fig. S12).

\section{Discussion}

\subsection{First estimates of pasture-associated fire}

Pasture fire accounts for about $43 \%$ of global annual burned area and about $22 \%$ of global C emissions from fire. Pasture burning is especially important in CEAS, NHSA, NHAF, SHAF, and SHSA, in each of which it accounts for over $40 \%$ of annual burned area. These regions together comprise $81 \%$ of mean annual burning. As with the global numbers, the fraction of annual fire emissions from pasture burning there is disproportionately small - only NHSA has pasture contributing more than $40 \%$ of $\mathrm{C}$ emissions (Fig. 3b). These results are not qualitatively different in the analysis with $\widehat{F}_{k}$ values constrained to zero or above (Appendix A).

In most regions, the seasonality of pasture burning is roughly similar to that of non-agricultural land. A tendency for pasture to burn earlier than non-agricultural land is apparent in NHSA, EURO, MIDE, NHAF, SEAS, and to some extent AUST (Fig. 6). The seasonality of these two fire types is notably different in CEAS, where pasture fire peaks in $\mathrm{Au}$ gust and non-agricultural fire peaks in May. During the peak of pasture burning in that region, non-agricultural land exerts a negative influence on total burning (Fig. 6). Some insight into the interplay of the different land-use types in this region, as well as the intricacies involved in interpreting the estimates from our method, can be gleaned from a more detailed look at pasture and other fire in CEAS. Most of the negative influence of non-agricultural land is concentrated in northern Kazakhstan and surrounding Russia. This is also the subregion where most pasture fire is concentrated during its July-August-September peak, which corresponds to the strongest negative influence of non-agricultural land. Taken together, these details suggest that there is at least some uncontrolled burning happening on pasture there at that time, since the presence of other land (presumably less-flammable vegetation types such as forest) appears to reduce pasture fire, likely by fragmenting the burnable landscape.

\subsection{Input data quality}

As with all data analysis, the performance of this algorithm is restricted by how well its input data represent the real world. Errors in the data sets of either land use or burned area will propagate through to the $\widehat{F}_{k}$ estimates and partitioned maps of fire by land-use type.

The first step in the development of the HYDE land-use data set was the production of a map of cropland and pasture representative of their distribution during the period 19902000. By reconciling remote-sensing maps of land cover with country-level area totals from the FAO, HYDE represented a significant advance over previous methods (Klein Goldewijk et al., 2007, 2010). However, the FAO numbers themselves may not be completely internally consistent, since they are compiled and reported by each country. A wide variety of ecosystem types and land-use patterns might all qualify as what the FAO terms "permanent pasture", and countries' standards of what to report likely differ (Klein Goldewijk et al., 2007). Differing methods of compilation introduce another source of uncertainty.

By incorporating active fire detections as an ancillary source of "burned area" information, the algorithm used in GFED3s was designed to avoid (as much as possible) the issue of fires much smaller than a single sensor pixel being excluded (Randerson et al., 2012). Even though GFED3s includes much more cropland fire than GFED3, it likely still misses much such burning. For example, McCarty et al. (2009) used fieldwork to inform a remote sensing estimate of cropland burning in the contiguous US and found that an average of more than $1.2 \mathrm{Mhayr}^{-1}$ burned between 2003 and 2007; during the same period, GFED3s has only $0.67 \mathrm{Mha} \mathrm{yr}^{-1}$ (or $0.93 \mathrm{Mha} \mathrm{yr}^{-1}$ if also including croplandnatural mosaic). Moreover, the "small fires" improvement may not have improved the detection of burning underneath 
(a)

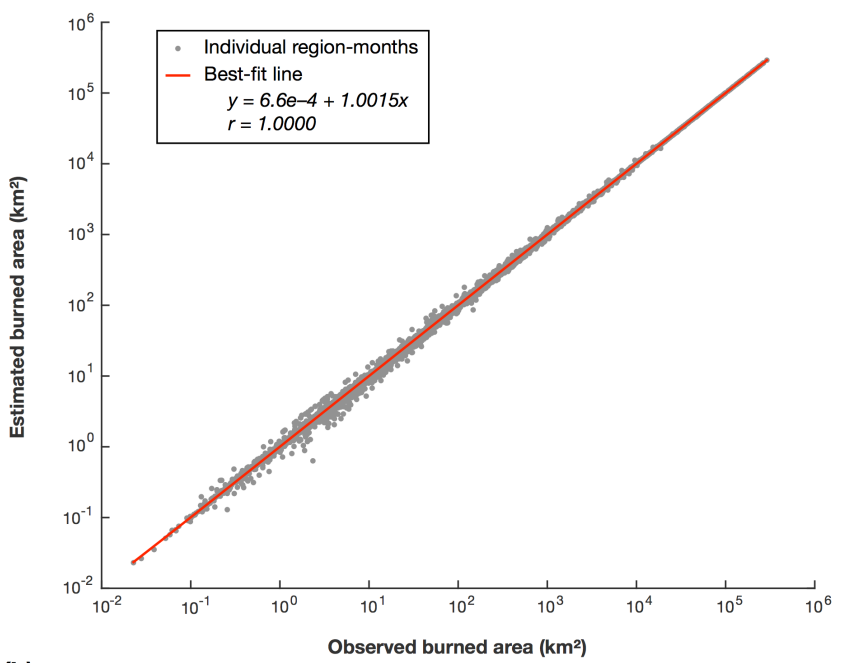

(b)

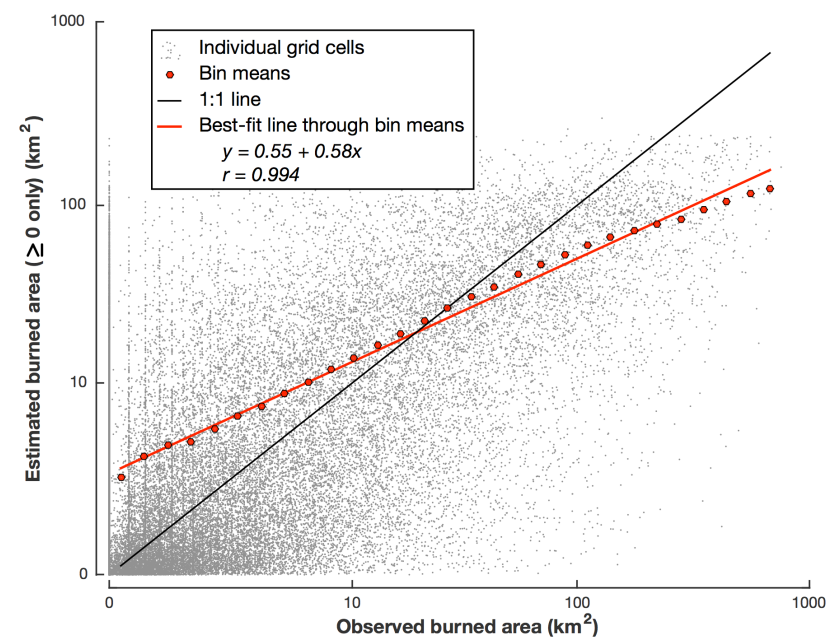

Figure 8. Scatterplots comparing estimated and observed total burned area. Gray points represent (a) each analysis region and month (region-month) or (b) individual grid cells ( $\frac{1}{75}$ of cells chosen at random for plotting). Red lines represent the best-fit line from linear regression, with the regression in (b) fit to the red points, which represent mean observed and estimated values of grid cells in bins of observed burned area equally spaced along the $x$ axis (with at least 100 grid cells required for a bin to be included). Values $\leq 0$ not shown due to log-scale axes. Grid cells in region-months with no observed fire, where the analysis was not performed, were excluded from both plots and regressions. Corresponds to Fig. S13.

a relatively undamaged canopy, which poses a challenge even for active fire sensors and algorithms (Giglio, 2013). In regions of southern Africa with tree cover $\geq 21 \%$, this was blamed for a $41 \%$ underestimate of burned area in an assessment of the algorithm underlying most of GFED3 (Giglio et al., 2009); a similar assessment has not been performed for GFED3s.

\subsection{Impacts of regional analysis}

The specific set of regions chosen for this analysis can be important for the quality of the results. One aspect to consider is that analysis regions that are too extensive may encompass too many different fire patterns for any one set of $\widehat{F}_{k}$ values to describe well. This may have been the cause of the poor performance in EURO and MIDE with regard to total fire (Fig. 3): both include parts of one or more very large analysis regions (Fig. 1). Fire is much more frequently used to manage croplands in the eastern part of the large EURO analysis region than in the west (Lin et al., 2012). This could be due to different crops being grown, but this seems unlikely since wheat and maize comprise most of the cropland across the region (Leff al., 2004). Instead, differences in cultural history, policies regulating residue burning, and economic conditions probably play a large role. Breaking the large region into more fine-grained regions would likely better account for this heterogeneity in fire patterns and practices.

On the other hand, analysis regions that are too small specifically, those that do not sample grid cells with a wide range of values for each land cover type - may serve to confound the results. In an extreme example, a region that had no cropland would be assigned $\widehat{F}_{c}=0$. However, because no cropland was observed, the true effect cropland would have in the region might actually be different from zero. In a less extreme case, burning patterns might be controlled mostly by the influence of one dominant land cover type. This sort of effect could be at play in BOAS, for example, where (as discussed above) total regional burned area is estimated accurately despite its containing several large regions.

Another, more general consequence of the regional analysis is that spatial heterogeneity of burning within analysis regions is not well represented in the results. As expected based on the mathematics involved in the parameterization, the total estimated amount of fire at the regional level is usually quite accurate (Fig. 8a) - estimated total burned area was correct to within $5 \%$ in $86 \%$ of region-months with fire observed. A best-fit line through a plot of the total observed vs. estimated burned area of all region-months illustrates this. With a slope near one, intercept near zero, and high value of Pearson's $r$, most of the estimated means lie near the oneto-one line. On a finer-grained level, a best-fit line through the mean estimated burned area of bins of grid-cell-level observed burned area, equally spaced on a log scale, shows that the algorithm tends to overestimate burning where there is little observed fire and underestimate where observed burning is high (Fig. 8b), but the scatter of individual grid cells around these binned averages is large. Especially noticeable is the large number of grid cells with zero (or very little) observed fire that are overestimated by the algorithm. When calculated across all grid cells in all months, the coefficient of determination $R^{2}=0.356$, indicating that only just over a third of the variation in spatiotemporal patterns of fire can be explained by land-use distributions. More of the variabil- 
ity is due to factors governing fuel availability and moisture, such as net primary productivity, temperature, precipitation, and humidity (Bistinas et al., 2014; Lasslop et al., 2015). In region-months where land cover distributions have very low explanatory power, the individual $\widehat{F}_{k}$ values should tend towards the total fraction of land burned.

The maps in Fig. 5 illustrate this problem in a more intuitive format. Although fire activity is usually well characterized at the level of the analysis region (as illustrated by Fig. 8a), Fig. 5 shows that it does not fully incorporate the heterogeneity evident in the observations as illustrated by Fig. 8b). Thus, interpretations of the maps in Fig. 4 should focus on general patterns without delving too deeply into grid cell by grid cell variation.

Finally, because the GFED region boundaries do not all correspond to those of the analysis regions, GFED regions without much fire are highly sensitive to inclusion of parts of analysis regions with too much or too little estimated fire. This also may have contributed to the poor performance in EURO and MIDE (Fig. 3). For example, Afghanistan (MIDE) is included in analysis region 26, "west-central Asian desert steppe" (AR26), which is not completely contained by MIDE. Afghanistan is an area of overestimate in AR26, and although it is balanced out by underestimates elsewhere in that region (especially along its northern boundary), MIDE only includes the overestimate. This effect, then, contributes to the net overestimate in MIDE.

\section{Conclusions}

The analysis presented here shows that agriculture does have far-reaching consequences on vegetation fire, often in ways not previously measured or considered at large scales. The widely acknowledged suppressive effect of cropland (Archibald et al., 2009; Andela and van der Werf, 2014) is quantified by broadening the scope of land-use associations with burning to include fire prevented on other land-use types. Pasture, previously not considered as a distinct landuse type in estimates of fire activity since it is not mapped globally at high resolution, is shown to account for nearly half of global annual burned area (Fig. 2a). Importantly, analysis at the regional and monthly level elucidates for the first time variations in management practices and other patterns across space and time. For example, although cropland has a net suppressive effect in parts of the world such as Southeast Asia, it enhances fire activity in regions such as southern Mexico (Fig. 4a). Even within a given region, such as the one examined in western Africa (Fig. 7), cropland can have either an enhancing or suppressive effect on fire, depending on the time of year (Figs. 6, S8-S11).

These new estimates of burning associated with cropland, pasture, and other land could be used for a variety of purposes. For example, a lack of data has contributed to cropland and pasture management burning being mostly ignored in global fire models (although see Li et al., 2013; Pfeiffer et al., 2013); the results from this work could inform the development of mechanisms to account for such practices. Future development of this algorithm could add terms to explicitly account for interactions between land uses, such as cropland suppressing fire on non-agricultural land. This would generate estimates of burning on cropland separate from its effect on other land-use types, further improving the utility of the results.

\section{The Supplement related to this article is available online at doi:10.5194/bg-12-6591-2015-supplement.}

Acknowledgements. The authors would like to acknowledge funding for this work from the Carbon Mitigation Initiative, as well as a National Science Foundation Graduate Research Fellowship award to S. S. Rabin. B. I. Magi was partially supported by NSF grant BCS-1436496. We also thank K. Klein Goldewijk for sharing annual HYDE data, and James Randerson for granting early access to the GFED3s data set. Finally, we thank Paul Laris and the two anonymous referees for valuable feedback that improved this paper.

Edited by: T. Keenan

\section{References}

Andela, N. and van der Werf, G. R.: Recent trends in African fires driven by cropland expansion and El Niño to La Niña transition, Nature Climate Change, 4, 791-795, 2014.

Archibald, S., Roy, D. P., van Wilgen, B. W., and Scholes, R.: What limits fire? An examination of drivers of burnt area in Southern Africa, Glob. Change Biol., 15, 613-630, 2009.

Archibald, S., Staver, A. C., and Levin, S. A.: Evolution of humandriven fire regimes in Africa, P. Natl. Acad. Sci. USA, 109, 847852, 2012.

Archibald, S., Lehmann, C. E. R., Gomez-Dans, J. L., and Bradstock, R. A.: Defining pyromes and global syndromes of fire regimes, P. Natl. Acad. Sci. USA, 110, 6442-6447, 2013.

Arora, V. K. and Boer, G.: Fire as an interactive component of dynamic vegetation models, J. Geophys. Res., 110, 1-20, 2005.

Bistinas, I., Oom, D., Sá, A. C. L., Harrison, S. P., Prentice, I. C., and Pereira, J. M. C.: Relationships between human population density and burned area at continental and global scales, PLoS One, 8, e81188, doi:10.1371/journal.pone.0081188.t003, 2013.

Bistinas, I., Harrison, S. P., Prentice, I. C., and Pereira, J. M. C.: Causal relationships versus emergent patterns in the global controls of fire frequency, Biogeosciences, 11, 5087-5101, doi:10.5194/bg-11-5087-2014, 2014.

Bond, T. C., Doherty, S. J., Fahey, D. W., Forster, P. M., Berntsen, T., DeAngelo, B. J., Flanner, M. G., Ghan, S., Kärcher, B., Koch, D., Kinne, S., Kondo, Y., Quinn, P. K., Sarofim, M. C., Schultz, M. G., Schulz, M., Venkataraman, C., Zhang, H., Zhang, S., Bellouin, N., Guttikunda, S. K., 
Hopke, P. K., Jacobson, M. Z., Kaiser, J. W., Klimont, Z., Lohmann, U., Schwarz, J. P., Shindell, D. T., Storelvmo, T., Warren, S. G., and Zender, C. S.: Bounding the role of black carbon in the climate system: a scientific assessment, J. Geophys. Res.Atmos., 118, 5380-5552, 2013.

Bond, W. J., Woodward, F. I., and Midgley, G. F.: The global distribution of ecosystems in a world without fire, New Phytol., 165, 525-538, 2005.

Bowman, D. M. J. S., Balch, J. K., Artaxo, P., Bond, W. J., Cochrane, M. A., D' antonio, C. M., DeFries, R., Johnston, F. H., Keeley, J. E., and Krawchuk, M. A.: The human dimension of fire regimes on Earth, J. Biogeogr., 38, 2223-2236, 2011.

Cheney, P. and Sullivan, A.: Grassfires: Fuel, Weather and Fire Behaviour, 2nd edn., CSIRO Publishing, Collingwood, Victoria, Australia, 2009.

Cochrane, M. A. and Schulze, M. D.: Forest fires in the Brazilian Amazon, Conserv. Biol., 12, 948-950, 1998.

Cox, P. M., Harris, P. P., Huntingford, C., Betts, R. A., Collins, M., Jones, C. D., Jupp, T. E., Marengo, J. A., and Nobre, C. A.: Increasing risk of Amazonian drought due to decreasing aerosol pollution, Nature, 453, 212-215, 2008.

Crutzen, P. J. and Andreae, M. O.: Biomass burning in the tropics: impact on atmospheric chemistry and biogeochemical cycles, Science, 250, 1669-1678, 1990.

FAO: Concepts and Definitions, available at: http://faostat.fao.org/ site/375/default.aspx (last access: 18 June 2015), 2005.

Friedl, M., McIver, D., Hodges, J., Zhang, X., Muchoney, D., Strahler, A., Woodcock, C., Gopal, S., Schneider, A., Cooper, A., Baccini, A., Gao, F., and Schaaf, C.: Global land cover mapping from MODIS: algorithms and early results, Remote Sens. Environ., 83, 287-302, 2002.

Friedl, M. A., Sulla-Menashe, D., Tan, B., Schneider, A., Ramankutty, N., Sibley, A., and Huang, X.: MODIS Collection 5 global land cover: algorithm refinements and characterization of new datasets, Remote Sens. Environ., 114, 168-182, 2010.

Giglio, L.: MODIS Collection 5 Active Fire Product User's Guide Version 2.5, available at: https://earthdata.nasa.gov/files/ MODIS_Fire_Users_Guide_2.5.pdf (last access: 18 June 2015), 2013.

Giglio, L., van der Werf, G. R., Randerson, J. T., Collatz, G. J., and Kasibhatla, P.: Global estimation of burned area using MODIS active fire observations, Atmos. Chem. Phys., 6, 957974, doi:10.5194/acp-6-957-2006, 2006.

Giglio, L., Loboda, T., Roy, D. P., Quayle, B., and Justice, C. O.: An active-fire based burned area mapping algorithm for the MODIS sensor, Remote Sens. Environ., 113, 408-420, 2009.

Giglio, L., Randerson, J. T., van der Werf, G. R., Kasibhatla, P. S., Collatz, G. J., Morton, D. C., and DeFries, R. S.: Assessing variability and long-term trends in burned area by merging multiple satellite fire products, Biogeosciences, 7, 1171-1186, doi:10.5194/bg-7-1171-2010, 2010.

Hantson, S., Lasslop, G., Kloster, S., and Chuvieco, E.: Anthropogenic effects on global mean fire size, Int. J. Wildland Fire, 24, 589-596, 2010.

Hurtt, G. C., Chini, L. P., Frolking, S., Betts, R. A., Feddema, J., Fischer, G., Fisk, J. P., Hibbard, K., Houghton, R. A., Janetos, A., Jones, C. D., Kindermann, G., Kinoshita, T., Klein Goldewijk, K., Riahi, K., Shevliakova, E., Smith, S., Stehfest, E., Thomson, A., Thornton, P., van Vuuren, D. P., and Wang, Y. P.:
Harmonization of land-use scenarios for the period 1500-2100: 600 years of global gridded annual land-use transitions, wood harvest, and resulting secondary lands, Climatic Change, 109, 117-161, 2011.

Klein Goldewijk, K., van Drecht, G., and Bouwman, A. F.: Mapping contemporary global cropland and grassland distributions on a 5x5 minute resolution, J. Land Sci., 2, 167-190, 2007.

Klein Goldewijk, K., Beusen, A., Van Drecht, G., and De Vos, M.: The HYDE 3.1 spatially explicit database of human-induced global land-use change over the past 12000 years, Global Ecol. Biogeogr., 20, 73-86, 2010.

Korontzi, S., McCarty, J., Loboda, T., Kumar, S., and Justice, C.: Global distribution of agricultural fires in croplands from 3 years of Moderate Resolution Imaging Spectroradiometer (MODIS) data, Global Biogeochem. Cy., 20, GB2021, doi:10.1029/2005GB002529, 2006

Laris, P.: Burning the seasonal mosaic: preventative burning strategies in the wooded savanna of southern Mali, Hum. Ecol., 30, 155-186, 2002.

Lasslop, G., Hantson, S., and Kloster, S.: Influence of wind speed on the global variability of burned fraction: a global fire model's perspective, Int. J. Wildland Fire, 22, 959-969, 2015.

Leff, B., Ramankutty, N., and Foley, J.A.: Geographic distribution of major crops across the world, Global Biogeochem. Cy., 18, GB1009, doi:10.1029/2003GB002108, 2004.

Lenihan, J., Daly, C., Bachelet, D., and Neilson, R.: Simulating broad-scale fire severity in a dynamic global vegetation model, Northwest Sci., 72, 91-101, 1998.

Le Page, Y., Oom, D., Silva, J. M. N., Jönsson, P., and Pereira, J. M. C.: Seasonality of vegetation fires as modified by human action: observing the deviation from eco-climatic fire regimes, Global Ecol. Biogeogr., 19, 575-588, 2010.

Le Page, Y., Morton, D., Bond-Lamberty, B., Pereira, J. M. C., and Hurtt, G.: HESFIRE: a global fire model to explore the role of anthropogenic and weather drivers, Biogeosciences, 12, 887-903, doi:10.5194/bg-12-887-2015, 2015.

Li, F., Levis, S., and Ward, D. S.: Quantifying the role of fire in the Earth system - Part 1: Improved global fire modeling in the Community Earth System Model (CESM1), Biogeosciences, 10, 2293-2314, doi:10.5194/bg-10-2293-2013, 2013.

Lin, H.-S., Jin, Y., Giglio, L., Foley, J.A., and Randerson, J.T.: Evaluating greenhouse gas emissions inventories for agricultural burning using satellite observations of active fires, Ecol. Apps., 22, 1345-1364, 2012.

Magi, B. I., Rabin, S., Shevliakova, E., and Pacala, S.: Separating agricultural and non-agricultural fire seasonality at regional scales, Biogeosciences, 9, 3003-3012, doi:10.5194/bg-9-30032012, 2012.

Marlon, J., Bartlein, P. J., Carcaillet, C., Gavin, D. G., Harrison, S. P., Higuera, P. E., Joos, F., Power, M. J., and Prentice, I. C.: Climate and human influences on global biomass burning over the past two millennia, Nat. Geosci., 1, 697-702, 2008.

Myhre, G., Shindell, D. T., Bréon, F.-M., Collins, W., Fuglestvedt, J., Huang, J., Koch, D., Lamarque, J.-F., Lee, D., Mendoza, B., Nakajima, T., Robock, A., Stephens, G., and Zhang, H.: Anthropogenic and Natural Radiative Forcing, Cambridge University Press, Cambridge, UK and New York, NY, USA, 659740, 2013. 
Olson, D. M., Dinerstein, E., Wikramanayake, E. D., Burgess, N. D., Powell, G. V., Underwood, E. C., D'amico, J. A., Itoua, I., Strand, H. E., and Morrison, J. C.: Terrestrial ecoregions of the world: a new map of life on Earth: a new global map of terrestrial ecoregions provides an innovative tool for conserving biodiversity, Bioscience, 51, 933-938, 2001.

Pechony, O. and Shindell, D. T.: Fire parameterization on a global scale, J. Geophys. Res., 114, D16115, doi:10.1029/2009JD011927, 2009.

Pfeiffer, M., Spessa, A., and Kaplan, J. O.: A model for global biomass burning in preindustrial time: LPJ-LMfire (v1.0), Geosci. Model Dev., 6, 643-685, doi:10.5194/gmd-6-643-2013, 2013.

Pyne, S. J., Andrews, P. L., and Laven, R. D.: Fire and culture, in: Introduction to Wildland Fire, John Wiley and Sons, New York, 213-307, 1996a.

Pyne, S. J., Andrews, P. L., and Laven, R. D.: Fire ecology, in: Introduction to Wildland Fire, John Wiley and Sons, New York, 171-212, 1996b.

Randerson, J. T., Chen, Y., van der Werf, G. R., Rogers, B. M., and Morton, D. C.: Global burned area and biomass burning emissions from small fires, J. Geophys. Res., 117, G04012, doi:doi:10.1029/2012JG002128, 2012.

Scott, A. C., Bowman, D. M. J. S., Bond, W. J., Pyne, S., and Alexander, M. E.: Pyrogeography-temporal and spatial patterns of fire, in: Fire on Earth: An Introduction, John Wiley \& Sons, West Sussex, UK, 113-129, 2014.
Seiler, W. and Crutzen, P. J.: Estimates of gross and net fluxes of carbon between the biosphere and the atmosphere from biomass burning, Climatic Change, 2, 207-247, 1980.

Taylor, K. E., Stouffer, R. J., and Meehl, G. A.: An overview of CMIP5 and the experiment design, B. Am. Meteorol. Soc., 93, 485-498, 2012.

Thonicke, K., Spessa, A., Prentice, I. C., Harrison, S. P., Dong, L., and Carmona-Moreno, C.: The influence of vegetation, fire spread and fire behaviour on biomass burning and trace gas emissions: results from a process-based model, Biogeosciences, 7, 1991-2011, doi:10.5194/bg-7-1991-2010, 2010.

Uhl, C. and Buschbacher, R.: A disturbing synergism between cattle ranch burning practices and selective tree harvesting in the eastern Amazon, Biotropica, 17, 265-268, 1985.

van der Werf, G. R., Randerson, J. T., Giglio, L., Collatz, G. J., Mu, M., Kasibhatla, P. S., Morton, D. C., DeFries, R. S., Jin, Y., and van Leeuwen, T. T.: Global fire emissions and the contribution of deforestation, savanna, forest, agricultural, and peat fires (19972009), Atmos. Chem. Phys., 10, 11707-11735, doi:10.5194/acp10-11707-2010, 2010.

Venevsky, S., Thonicke, K., Sitch, S., and Cramer, W.: Simulating fire regimes in human-dominated ecosystems: Iberian Peninsula case study, Glob. Change Biol., 8, 984-998, 2002.

Ward, D. S., Kloster, S., Mahowald, N. M., Rogers, B. M., Randerson, J. T., and Hess, P. G.: The changing radiative forcing of fires: global model estimates for past, present and future, Atmos. Chem. Phys., 12, 10857-10886, doi:10.5194/acp12-10857-2012, 2012.

Yevich, R. and Logan, J. A.: An assessment of biofuel use and burning of agricultural waste in the developing world, Global Biogeochem. Cy., 17, 1095, doi:10.1029/2002GB001952, 2003. 